\title{
A Cultural E-Government Readiness Model
}

\author{
Alia Sabri ${ }^{1}$, Omar Sabri ${ }^{2}$, Bassam Al-Shargabi $^{3}$ \\ ${ }^{1}$ Faculty of Information Technology, Applied Sciences University, Amman, Jordan \\ ${ }^{2}$ Faculty of Management Science, Isra University, Amman, Jordan \\ ${ }^{3}$ Faculty of Information Technology, Isra University, Amman, Jordan \\ Email: a_sabri@asu.edu.jo,omarsabri@yahoo.com, bassam20_152@yahoo.com
}

Received May 3, 2012; revised June 10, 2012; accepted June 25, 2012

\begin{abstract}
E-Government is defined as a system utilizing the Internet and the world-wide-web for delivering government information and services to citizens. This system reduces the processing costs, improves service delivery, and increases transparency and communication between a government and its citizens. The aim of this paper is to propose a new model to measure the readiness of e-Government according to cultural factors. By assessing to which degree these cultural factors are present/absent in a country and which of them have a significant impact on government readiness, the government will be able to identify their weakness and strength points, then build a preparing plan that can help them to achieve the readiness required toward a successful implementation of the e-Government systems.
\end{abstract}

Keywords: Cultural Dimension; E-Government Readiness; E-Government Initiative; E-Governments Factors

\section{Introduction}

E-Government application remain at the top of most countries policy agendas $[1,2]$. The emphasis on the eGovernment may be due to the potential of ICT to transform public administration to an efficient system, enhance public services quality, people life, establish trust between public administration and citizens and realize economic objectives [1,3,4]. Many governments around the world find it very difficult to accept e-Government, because they have to change entire governance procedures [5]. However, governments that succeeded in implementing e-Government had suggested strategies to improve their own model that is suitable for each country's, political, economical, technological and cultural environment [6].

The implementation of e-Government systems is extremely complex [7]. To succeed in the implementation of these systems, a preparing process is required. The aim of this process is to achieve a readiness in a government to be able to implement these systems effectively and efficiently. One of the most important reasons for success and failure of e-Government is the cultural issue and more precisely how do citizens accept the new technology [8]. Several studies like [9,10]; discussed the importance and the relationship of technology and cultures sectors to provide successful e-Government projects in most countries and exploring causal factors including different cultures related to information and communication technology (ICT) adoption that have been carried out. Many studies demonstrate how culture might relate to
ICT use in many countries like Iran [11]; Indonesia [12]; Korean Public [13]; Saudi Arabia [14]; United Kingdom [7].

However, there are many cultural factors that affect this process. Identifying which of these factors should be considered in the preparing process is not an easy task, and hence, this study intent to investigate and identify the cultural factors that will lead the developing countries toward a successful readiness of implementation of the e-Government systems. By assessing to which degree these cultural factors are present/absent in the government and which of them have a significant effect on government readiness, the government will be able to identify their weakness and strength points, then build a preparing plan that can help them achieve the readiness required toward a successful implementation of the e-Government systems.

This paper will be organized as the following: The most recent and related work is presented in Section 2. In Section 3 we present Hofstede's cultural dimensions. The proposed cultural e-Government readiness model is introduced and discussed in Section 4. Finally, a number of conclusions are drawn and recommendations for future work are pointed-out.

\section{Background}

E-Government has numerous definitions vary among people; it refers to the use by governments of ICT and web based Internet applications and, combined with processes that implement these technologies, to improve the 
access to and delivery of government information and services to the public, other agencies, and other government entities at all time or bring about improvements in government operations $[15,16]$. This definition shows the electronic interaction between the government, the public and the employees. E-Government is also defined as a way for governments to use the most innovative ICTs to improve the quality of the services and to provide greater opportunities to participate in democratic institutions and processes $[17,18]$ concentrate on the definition of e-Government on the efficient services applied by e-Government include the speed, the functionality, the ease of use, and the cost of information processing. They also concentrate on how much the actual e-Government performance achieves its objectives. [19] defines e-Government system as a modern and an expected improvement due to the rapid development of ICT, which has been used in many regions, particularly business known as ebusiness to improve the services provided to their customers, as well as to achieve a broader range of population.

The benefits of the use of e-Government application are the same for both developing and developed countries [20]. These benefits are: support good governance [21], cost saving and efficiency gains [9], improve the service delivery to businesses and customers [22], transparency, anticorruption, accountability, increase capacity and improve network infrastructure of governments, and improve the quality of decision making [23].

One key to the success of government transformation is the development of the individual's culture [24]. Hofstede, in [25], defines culture as the collective programming of the mind which distinguishes the members in one human group from another. Others as in [26] inform that culture is a critical variable in explaining how social groups interact with IT, while Martinsons in [27] defines culture as a collective programming of the mind that distinguishes not only societies (or nations) but also Industries, professions, and organizations.

There are many approaches to classify and test cultures. The most and best particular classification is Hofstede's. His cultural dimensions values are: Power Distance (PD), Uncertainty Avoidance (UA), Individualism (IDV), Masculinity (MAS), and Long-Term Orientation (LTO) [28]. A theoretical framework is presented in [5] for the impact of national culture on information and communication technology (ICT) and to test whether the national cultural dimensions have significant impact on the ICT.

Few studies have concentrated on the impact of national cultural factors such as Hofstede's cultural dimensions as used in many researches related to e-Government and other factors such as individual's behavior, acceptance, trust, skills and engagement in the acceptance of eGovernment systems implementation as mentioned by [14, $29,30]$.

\section{Cultural Factors: Hofstede’s Cultural Dimensions}

A few of e-Government researches concern on cultural factors that affects on e-Government readiness and most of them pay attention to success factors for e-Government systems implementation. Hofstede's approach of culture and in particular his five dimensions are the most studied when considering ICT adoption at a national level [5]. In this paper, we are interested in exploring the potential factors of culture that influence on the readiness of eGovernment implementation. This research will be most useful for developing countries where understanding their cultures and their readiness to accept e-Government will lead to a successful implementation of e-Government.

Geert Hofstede presented five cultural dimensions (Power Distance, Uncertainty Avoidance, Individualism, Masculinity, and Long Term Orientation) as unique vectors that make countries distinguishable [25,28,31]. His cultural dimensions have been used and applied widely to understand business systems and practices and across most (if not all) of the behavioral science disciplines, including: compensation practices; management and marketing; advertising strategy; budget control practices; entrepreneurial behavior; conflict resolution; workgroup dynamics and performance; innovation; training design; leadership styles; management control systems; participative management [32], and examine organizational identification and employee turnover intentions, and to compare stereotypes across different cultures. Hofsted's dimensions are described as follows [31]:

Power Distance is related to the extent to which the less powerful members of group accept and expect that power is distributed unequally in a concrete society. They implied that organization with high power distance culture will miss the opportunity for better competence, while Culture with low power distance opens possibilities for expanding organization's competence since it takes into consideration individual and collective knowing based on tacit knowledge.

Uncertainty Avoidance deals with a society's ability to solve uncertainty and ambiguity problems, the extent to which people feel the threat of unstructured situations and try to avoid them. They implied that organizations with high uncertainty avoidance are characterized by low creativity level and vice versa.

Individualism refers the degree to which individual interests have the priority over group interests. Organizations characterized with high individualism level are concentrating on persuasion, while organizations characterized with high collectivism level are concentrating on creating trust [31].

Masculinity highlights the relationship between personal and professional goals in society and defines what society's members prefer: goal attainment or task perfor- 
mance. A significant aspect of this dimension is task differentiation: small in feminine societies, large in masculine societies. Masculinity focuses on achievement where as femininity focuses on quality of life.

Long-Term Orientation refers to the degree to which a culture values its tradition and how much individuals focus on their past and future [32] (Czech Republic, Slovakia, Hungary, Poland) implied that high power distance, high uncertainty avoidance, high individualism and high masculinity define a-hard culture which is characterized by reducing competence. On the other hand low power distance, low uncertainty avoidance, low individualism and femininity form-soft culture which increases the chance of competence.

We can expect that long-term oriented cultures will perceive greater long-term benefits associated with the internet. Van Everdingen in [33] reported that long-term orientation had a significant positive impact on the adoption of an IT-based innovation.

\section{The Proposed Cultural E-Government Readiness Model}

In this paper, the researchers selected ten factors that lead to a readiness of e-Government systems implementation. The selection of these ten factors was based on two main criteria: 1) their importance and occurrence in many literatures by many authors; and 2) their fitness to the nature of this study. Furthermore, the researchers classify these factors into three areas (government, people, and agency). Figure 1 illustrates the proposed cultural e-Government readiness model.

It seems to the authors that one dimension may affect on the readiness of e-Government implantation is people culture. Where, the culture will take into consideration the classification of Hofsted's national level of culture. We also add another important cultural factor which is trust. As stated in [34], citizen trust in government and

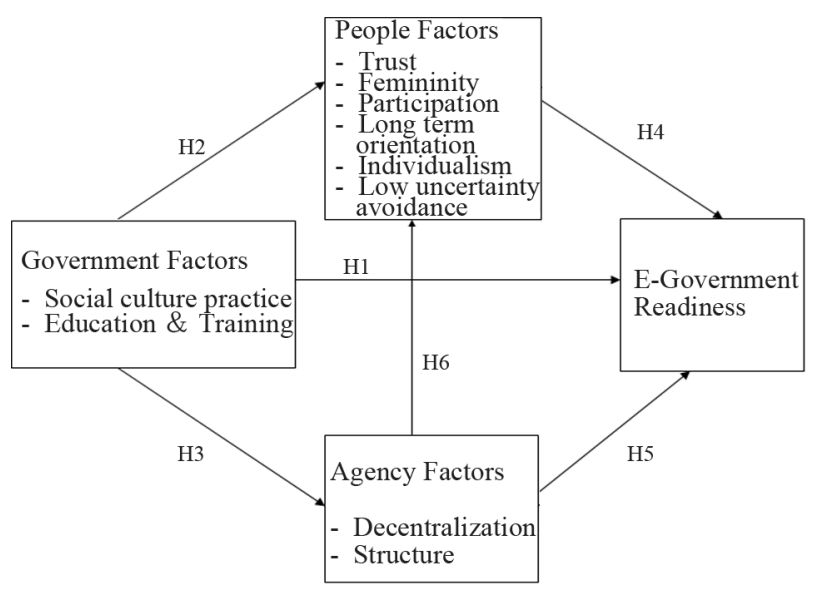

Figure 1. The proposed cultural e-Government readiness model. technology is very important to the wide-spread acceptance of e-Government. Trust in e-Government is therefore composed of the traditional view of trust in a specific entity (trust of government) as well as trust in the reliability of the enabling technology (trust of the Internet) [34]. Another important dimension is the agency culture as mentioned in [27], culture distinguishes organizations. We proposed two factors: decentralization and structure. For decentralization: the best way to enhance productivity is by allowing worker involvement into developing the mission statement, establishing policies and procedures, etc. [35]. It also enhances liability and monitoring of government officials and decision-makers. In [36] the authors stated that the degree of decentralization is positively related to educational attainment. Therefore, we expect that increasing the training and education factor will positively increase the decentralization factor.

On the other hand, the structure factor is considered here as a cultural factor of the public agencies and the managers themselves. In certain it is the same as the uncertainty avoidance but regarding to the leaders and managers, how do they react towards ambiguity and unstructured situations. In [37] found that in culture of high uncertainty avoidance Managers do not tend to take risks in decision making and responsibility, they are oriented to details, search for rules and instructions, and take detailed predetermined agreements. The third dimension is the government culture. We proposed two factors: Social Cultural Practices, and Training and Education, in [4] the authors stated that previous experience with governments has a major role in building trust. People suspicion about the government will be dissolved if the government treats all people fairly and lawfully. Also in [2] stated that eGovernment acceptance increases in countries where the level of education is high. As education level rises, so does usage of e-Government [38].

\section{Conclusions}

It can be concluded from this review of literature that, government, people and agencies cultural factors are more important than technological factors to implement e-Government systems successfully. This is because the culture of accepting new technology (e.g. lack of awareness, trust, uncertainty avoidance, etc.) is a critical issue that affects the success or failure of e-Government project. In addition, since the role of cultural values is emphasis to the internal and external characteristics of organization, it is important to study how these characteristics may effect on the implementation of e-Government.

In this paper, we proposed a model of the readiness of e-Government from cultural perspective. The basic building blocks of cultural e-Government readiness model are: government, people, and agencies. We selected ten cultural factors for each block depending on: 1) their im- 
portance and occurrence in many literatures by many authors; and 2) their fitness to the nature of this study.

By building the proposed e-Government readiness cultural model, each government who wishes to implement an e-Government initiative can use this model as a guideline to evaluate to which degree these cultural factors are present/absent in the government and which of them have a significant effect on government readiness. The government will be able to identify their weakness and strength point, and then build a preparing plan that can help them achieve the readiness required toward a successful implementation of the e-Government systems.

\section{Acknowledgements}

I would like to thank everyone who contributed to the completion of this work.

\section{REFERENCES}

[1] UN, "Global E-Government Readiness: Towards Access for Opportunity," United Nations, New York, 2004.

[2] F. Bouaziz, "Public Administration Presence on the Web: A Cultural Explanatio," The Electronic Journal of E-Government, Vol. 6, No. 1, 2008, pp. 11-22.

[3] N. Youssef, "UNDP/OECD Conference on Good Governance for Development in the Arab Countries," Dubai School of Government, Dubai, 2005.

[4] H. Al-Omari and A. Al-Omari, "Building an E-Government E-Trust Infrastructure," American Journal of Applied Sciences, Vol. 3, No. 11, 2006, pp. 2122-2130.

[5] Z. Kovačić, "The Impact of National Culture on Worldwide E-Government Readiness," Informing Science Journal, Vol. 8, 2005, pp. 143-158.

[6] V. Bekkers and M. Rebecca, "Visual Culture and Electronic Government: Exploring a New Generation of EGovernment," Proceedings of EGOV, Zaragoza, $30 \mathrm{Au}-$ gust - 3 September 2004, pp. 257-269.

[7] L. Carter and W. Vishanth, "E-Government Adoption: A Cultural Comparison," Springer Science, Vol. 10, No. 4, 2008, pp. 473-482.

[8] E. Welch, H. Charles and M. Jae, "Linking Citizen Satisfaction with E-Government and Trust in Government," Journal of Public Administration Research and Theory, Vol. 15, No. 3, 2004, pp. 371-391.

[9] J. C. Bertot, P. T. Jaeger and J. M.Grimes, "Using ICTs to Create a Culture of Transparency: E-Government and Social Media as Openness and Anti-Corruption Tools for Societies," Government Information Quarterly, Vol. 1, No. 8, 2010, pp. 1-8.

[10] M. Kettani and D. Taieb, "NCSec: A National Cyber Security Referential for the Development of a Code of Practice in National Cyber Security Management," Proceedings of the 2nd International Conference on Theory and Practice of Electronic Governance, Cairo, 1-4 December 2008.

[11] A. H. Moghadam and A. Parisa, "The Relationship be- tween National Culture and E-Adoption: A Case Study of Iran," American Journal of Applied Sciences, Vol. 5, No. 4, 2008, pp. 369-377.

[12] M. Sudarwan and J. F. Timothy, "Culture and Accounting in Indonesia: An Empirical Examination," The International Journal of Accounting, Vol. 31, No. 4, 1996, pp. 463-481.

[13] Y. Kim and Y. K. Soo, "The Influence of Cultural Values on Perceptions of Corporate Social Responsibility: Application of Hofstede's Dimensions to Korean Public Relations Practitioners," Journal of Business Ethics, Vol. 91, No. 4, 2010, pp. 485-500.

[14] S. S. Al-Gahtani, G. S. Hubona and J. Wang, "Information technology (IT) in Saudi Arabia: Culture and the Acceptance and Use of IT," Information \& Management, Vol. 44, No. 8, 2007, pp. 681-691.

[15] C. Baum and D. Andrian, "Gartner's Four Phases of EGovernment Model," 2001. http://gartner3.gartnerweb.com/public/static/hotc/000942 35.html

[16] UNPAN, "United Nations E-Government Survey: From E-Government to Connected Governance," Department of Economic and Social Affairs of United Nations, New York, 2008.

[17] Z. Fang, "E-Government in Digital Era: Concept, Practice, and Development," International Journal of the Computer, the Internet and Management, Vol. 10, No. 2, 2002, pp. 1-22.

[18] Y. N. Chen, H. M. Chen, W. Huang and R. K. Ching, "EGovernment Strategies in Developed and Developing Countries: An Implementation Framework and Case Study," Journal of Global Information Management, Vol. 14, No. 1, 2006, pp. 23-46.

[19] A. Alasem, "An Overview of E-Government Metadata Standards and Initiatives Based on Dublin Core," Electronic Journal of E-Government, Vol. 7, No. 1, 2006, pp. $1-10$.

[20] V. Ndou, "E-Government for Developing Countries: Opportunities and Challenges," The Electronic Journal on Information Systems in Developing Countries, Vol. 18, No. 1, 2004, pp. 1-24.

[21] L. Torres, P. Vicente and A. Basilio, "E-Governance Developments in European Union Cities: Reshaping Government's Relationship with Citizens," Governance, Vol. 19, No. 2, 2006, pp. 277-302.

[22] D. M. West, "Digital Government: Technology and Public Sector Performance," Princeton University Press, Princeton, 2005.

[23] J. W. Seifert and J. M. Glenn, "State E-Government Strategies: Identifying Best Practices and Applications," CRS Report for Congress, Washington DC, 2007.

[24] L. Wang and J. Anita, "Web Sites: Hofstede Revisited and the Relationship between National Culture and Organizational Culture Explored," International Communication Association, Vol. 1, 2005, pp. 1-31.

[25] G. Hofstede, "National Cultures in four Dimensions: A Research-Based Theory of Cultural Differences among Nations," International Studies of Management \& Orga- 
nization, Vol. 6, No. 1, 1983, pp. 46-74.

[26] D. Leidner and T. Kayworth, "A Review of Culture in Information Systems Research: Toward a Theory of Information Technology Culture Conflict," MIS Quarterly, Vol. 30, No. 2, 2006, pp. 357-399.

[27] M. G. Martinsons, M. D. Robert and M. Valdis, "How Culture Influences IT-Enabled Organizational Change and Information Systems," Communications of the ACM, Vol. 52, No. 2, 2009, pp. 118-123.

[28] G. Hofstede, "Culture's Recent Consequences: Using Dimension Scores in Theory and Research," International Journal of Cross Cultural Management, Vol. 1, No. 1, 2001, pp. 11-17.

[29] G. J. Tellis, S. Stefan and Y. Eden, "The International Takeoff of New Products: The Role of Economics, Culture, and Country Innovativeness," Marketing Science, Vol. 22, No. 2, 2003, pp. 188-208.

[30] W. E. Ebbers and J. A. G. M. Van Dijk, "Resistance and Support to Electronic Government, Building a Model of Innovation," Government Information Quarterly, Vol. 24, No. 3, 2007, pp. 554-575. doi:10.1016/j.giq.2006.09.008

[31] G. Hofstede and M. De Mooij, "The Hofstede Model Applications to Global Branding and Advertising Strategy and Research," Intemational Journal of Advertising, Vol. 29, No. 1, 2010, pp. 85-110.
[32] W. Gong, G. L. Zhan and L. S. Rodney, "Global Internet Use and Access: Cultural Considerations," Asia Pacific Journal of Marketing and Logistics, Vol. 19, No. 1, 2007, pp. 57-74.

[33] E. Van, M. Yvonne and W. Eric, "The Effect of National Culture on the Adoption of Innovations," Marketing Letters, Vol. 14, No. 3, 2003, pp. 217-232.

[34] F. Belanger and C. Lemuria, "Trust and Risk in E-Government Adoption," Journal of Strategic Information Systems, Vol. 17, No. 2, 2008, pp. 165-176.

[35] K. Bhatti and M. Tahir, "Impact of Employee Participation on Job Satisfaction, Employee Commitment and Employee Productivity," International Review of Business Research Papers, Vol. 3, No. 2, 2007, pp. 54-68,

[36] I. Barankay and L. Ben, "Decentralization and the Productive Efficiency of Government: Evidence from Swiss Cantons," Journal of Public Economics, Vol. 91, No. 5-6. 2007, pp. 1197-1218. doi:10.1016/j.jpubeco.2006.11.006

[37] J. F. Veiga, D. Kathleen and F. Steven, "Towards Modelling the Effects of National Culture on IT Implementation and Acceptance," Journal of Information Technology, Vol. 16, No. 3, 2001, pp. 145-158.

[38] P. T. Jaeger, “The Endless Wire: E-Government as Global Phenomenon," Government Information Quarterly, Vol. 20, No. 4, 2003, pp. 323-331. doi:10.1016/j.giq.2003.08.003 